\title{
Artikel
}

\section{Herziening ten voordele van de gewezen verdachte als buitengewoon rechtsmiddel}

Mr. dr. J.S. (Joost) Nan*

\section{NTS 2020/3}

\section{Inleiding}

Herziening in strafzaken is een delicaat onderwerp, in ieder geval al sinds het einde van de negentiende eeuw. Dat de mogelijkheid moet bestaan om onjuiste veroordelingen te redresseren is niet aan kritiek onderhevig. Hoe zorgvuldig de strafrechtspleging ook te werk gaat, onterechte veroordelingen zijn niet uit te sluiten. ${ }^{1}$ Maar hoe ruim de mogelijkheden voor herziening dienen te zijn, daarover blijven de meningen verdeeld. Het instrument ter herstel van rechterlijke dwalingen kenmerkt zich onder meer door aandacht en wijzigingen naar aanleiding van geruchtmakende zaken. Begin deze eeuw waren dat met name de Puttense moordzaak, de Deventer moordzaak en de Schiedammer Parkmoord. Per 1 oktober 2012 heeft het buitengewone rechtsmiddel herziening (thans: ten voordele), mede naar aanleiding van die zaken, voor het laatst behoorlijk wat veranderin-

* Mr. dr. J.S. Nan is universitair hoofddocent straf(proces)recht aan de Erasmus Universiteit Rotterdam en (cassatie)advocaat bij Wladimiroff Advocaten te Den Haag. Veel dank gaat uit naar student-assistente Julia Reis voor haar ondersteunende werk.

1. A.J. Blok \& L.Ch. Besier, Het Nederlandsche strafproces deel I, Haarlem: Tjeenk Willink 1925, p. 488; J.M. van Bemmelen, Strafvordering. Leerboek van het Nederlandse strafprocesrecht, 's-Gravenhage: Martinus Nijhoff 1950, p. 452; G.J.M. Corstens, M.J. Borgers \& T. Kooijmans, Het Nederlands strafprocesrecht, Deventer: Wolters Kluwer 2018, par. 17.7. Voor de mondiale ontwikkelingen, zie B.L. Garrett, 'Towards an International Right to Claim Innocence', California Law Review 2017, p. $1173-1221$. gen ondergaan. ${ }^{2}$ Dat geschiedde middels de Wet hervorming herziening ten voordele. ${ }^{3}$ De wet bracht vooral twee grote veranderingen. De ene verandering was een verruiming van het novumbegrip zelf (art. 457 lid 1 sub c Sv). ${ }^{4}$ De andere verandering was de invoering van de mogelijkheid voor de gewezen verdachte om in zware strafzaken ter voorbereiding van een herzieningsaanvraag, aan de procureur-generaal te verzoeken een nader onderzoek in te stellen naar de aanwezigheid van een novum (art. $461 \mathrm{~Sv}$ ). Daarbij werd de Adviescommissie afgesloten strafzaken (ACAS) in het leven geroepen om de procureur-generaal daarover te adviseren (art. 462

2. Zie over die aanloop onder andere P.A.M. Mevis, 'Verruiming van de herzieningsregeling?', DD 2007/16, afl. 3, p. 239-250; T. Kooijmans, 'Het novum als ingang van herziening', DD 2007/33, afl. 4, p. 410-432 en B.F. Keulen, 'Herziening van de herziening?', RM Themis 2007, afl. 1, p. 3-14. Zie voor de negentiende eeuw W.H. Borgman, Van herziening van arresten en vonnissen (diss. Utrecht), Utrecht: Den Boer 1899, p. 40 (omgekeerd was volgens Borgman het uitblijven van geruchtmakende zaken de reden dat een nieuwe regeling in die tijd op zich liet wachten).

3. Wet van 18 juni 2012 tot wijziging van het Wetboek van Strafvordering in verband met een hervorming van de regeling betreffende herziening ten voordele van de gewezen verdachte (Wet hervorming herziening ten voordele), Stb. 2012, 275; Besluit van 12 september 2012 tot vaststelling van het tijdstip van inwerkingtreding van de Wet hervorming herziening ten voordele, Stb. 2012, 404 en Kamerstukken I/ 2008/09, 32045. Zie in vogelvlucht $M$. Kessler, 'Wijziging herzieningsprocedure in strafzaken', AA 2013/9, p. 691-698. Zie per 1 oktober 2013 overigens ook herziening ten nadele van de gewezen verdachte middels de Wet van 13 april 2013 tot wijziging van het Wetboek van Strafvordering in verband met de invoering van een regeling betreffende herziening ten nadele van de gewezen verdachte (Wet herziening ten nadele), Stb. 2013, 138 en Kamerstukken // 2008/09, 32044.

4. Zie overzichtelijk over de nieuwe regeling ten voordele en ten nadele B.F. Keulen, Het stelsel van rechtsmiddelen in strafzaken (Preadvies NVVS 5 oktober 2012), Rotterdam: Wolf Legal Publishers 2012, par. 7. Zie ook de diverse bijdragen in de bundel F.W. Bleichrodt (red.), Herziening in strafzaken, Den Haag: Boom Juridische uitgevers 2011. 
Sv). Aan het werk van de Commissie Evaluatie Afgesloten Strafzaken (CEAS) kwam hierdoor een einde.

De Wet hervorming herziening ten voordele is in 2018 geëvalueerd op doeltreffendheid. Over de vraag of die wet de eerste vijf jaren doeltreffend is geweest, verschillen de meningen. ${ }^{5}$ Niet alleen de wetenschap ${ }^{6}$ blijft zich de inrichting en uitvoering van herziening ten voordele nog steeds aantrekken, maar ook de politiek, zo blijkt uit recente ontwikkelingen. ${ }^{7}$ Naast de meer praktische zaken als de financiering van rechtsbijstand en van nader onderzoek, spitst de parlementaire discussie zich inhoudelijk met name toe op twee punten om de drempel voor herziening via een novum te verlagen. Het eerste punt is welk criterium moet worden gehanteerd om een zaak op grond van een novum voor herziening in aanmerking te laten komen (kort gezegd: hoe sterk moet het nieuwe gegeven zijn?). Het tweede punt is welke taakopvatting de ACAS, als adviseur van de procureurgeneraal over de wenselijkheid van een nader onderzoek, behoort te hebben. Het zijn deze twee vraagpunten die ik in deze bijdrage bespreek. ${ }^{8}$

\section{Het novum en de wettelijke wortels van het ernstige vermoeden}

Artikel 457 lid 1 sub c Sv bepaalt sinds de recente wetswijziging dat de Hoge Raad een veroordeling kan herzien 'indien er sprake is van een gegeven dat bij het onderzoek op de terechtzitting aan de rechter niet bekend was en dat op zichzelf of in verband met de vroeger geleverde bewijzen met de uitspraak niet bestaanbaar schijnt, zodanig dat het ernstige vermoeden ontstaat dat indien dit gegeven bekend zou zijn geweest, het onderzoek van de zaak zou hebben geleid, hetzij tot een vrijspraak van de gewezen verdachte, hetzij tot een ontslag van alle rechtsvervolging, hetzij tot de niet-ontvankelijkverklaring van het Openbaar Ministerie, hetzij tot de toepassing van een minder zware strafbepaling'. Het wettelijke novumbegrip kent dus drie elementen.

5. Wel doeltreffend, zij het met enkele (potentiële) knelpunten: J.S. Nan, N.L. Holvast, S.M.A. Lestrade, P.A.M. Mevis \& P. Mascini, Victa vincit veritas? Evaluatie Wet hervorming herziening ten voordele, Den Haag: WODC 2018. Niet doeltreffend: G.G.J.A. Knoops, 'Herziening in strafzaken anno 2018. Ten voordele of ten nadele?', NJB 2018/1646, afl. 31, p. 2322-2328.

6. De Koninklijke Nederlandse Akademie van Wetenschappen hield op 13 september 2018 een bijeenkomst over gerechtelijke dwalingen. Zie naar aanleiding daarvan het themanummer 'Gerechtelijke dwalingen en herziening', E\&R 2018, afl. 6.

7. Aanhangsel Handelingen I/ 2018/19, nr. 3304 (vragen en antwoorden over het verlagen van drempels voor de herziening van afgesloten strafzaken); Kamerstukken II 2018/19, 29279, 495; Rondetafelgesprek vaste commissie voor Justitie en Veiligheid 22 mei 2019, Den Haag, over evaluatie Wet hervorming herziening ten voordele en Kamerstukken I/ 2019/20, 29279, 543.

8. Voor enige ontwikkelingen onder de nieuwe wet zij ook verwezen naar K.C.J. Vriend, 'Herziening van strafzaken: recente ontwikkelingen', DD $2017 / 69$.
Het moet gaan om (1) 'een gegeven', (2) waarmee de rechter niet bekend was en (3) waardoor het ernstige vermoeden ontstaat dat, ware dit gegeven wel bekend geweest, vrijspraak etc. zou zijn gevolgd.

De verruiming hield in dat niet langer 'eene omstandigheid', die van feitelijke aard moest zijn, vereist werd. ${ }^{9}$ Elk 'gegeven' zou zonder problemen tot herziening moeten kunnen leiden, ook als dat geen feitelijke vaststelling zou betreffen. In het bijzonder ging het om een (gewijzigd) deskundigeninzicht. ${ }^{10}$ Deze verruiming wordt als een verbetering gezien en daarvoor werd ook wel gepleit. ${ }^{11}$ De ervaring leerde overigens dat de Hoge Raad op zich met de oude formulering wel uit de voeten kon als herziening angewezen leek, maar een feitelijke omstandigheid zich niet zonder meer aandiende. Met de nieuwe redactie hoeft de Hoge Raad in dergelijke gevallen niet gekunsteld tot een novum te komen. ${ }^{12}$

In de wetsgeschiedenis is niet duidelijk omschreven wat nu precies onder een gegeven moet worden verstaan. Dat was aan de rechtspraak. ${ }^{13}$ Uit de rechtspraak van de Hoge Raad is vooral op te maken wat allemaal geen gegeven oplevert, waaronder rechtsdwaling, een veranderde rechtsopvatting, of een andere maatschappelijke opvatting over de strafwaardigheid van het bewezenverklaarde feit. ${ }^{14}$ Een onvolledig onderzoek van de zaak levert ook geen grond voor herziening op. ${ }^{15}$ Met Bleichrodt valt er daarom veel voor te zeggen om niet het 'gegeven' als onderscheidend onderdeel van het novumcriterium

9. Onder het oude recht was bepaald dat in geval van een novum herziening kon worden aangevraagd (art. 457 lid 1 sub 2 (oud) Sv): ‘op grond van eenige omstandigheid die bij het onderzoek op de terechtzitting den rechter niet was gebleken en die op zich zelve of in verband met de vroeger geleverde bewijzen met de uitspraak niet bestaanbaar schijnt in dier voege dat ernstig vermoeden ontstaat dat ware zij bekend geweest, het onderzoek der zaak zou hebben geleid, hetzij tot vrijspraak van den veroordeelde, hetzij tot ontslag van rechtsvervolging op grond dat deze niet strafbaar was, hetzij tot niet-ontvankelijkverklaring van het openbaar ministerie, hetzij tot toepasselijkverklaring van eene minder zware strafbepaling'.

10. Daarover J.S. Nan, N.L. Holvast, S.M.A. Lestrade, P.A.M. Mevis \& P. Mascini, Victa vincit veritas? Evaluatie Wet hervorming herziening ten voordele, Den Haag: WODC 2018, par. 2.3; HR 26 april 2014, ECLI:NL:HR:2016:736, NJ 2016/305 m.nt. J.M. Reijntjes en HR 17 april 2018, ECLI:NL:HR:2018:605, SR Updates 2018-0153 m.nt. J.S. Nan.

11. Zie bijvoorbeeld B.F. Keulen, 'Herziening van de herziening?', RM Themis 2007, afl. 1, p. 9: 'Moet niet elk gegeven dat het (ernstig) vermoeden doet rijzen dat de rechter bij bekendheid tot een andere materiële einduitspraak was gekomen, in beginsel tot herziening kunnen leiden?' Of wel sprake was van een verruiming, moest volgens Duker nader worden onderbouwd. Zie $M$. Duker, 'Het nieuwe novumbegrip in de herzieningsregeling verdient nadere toelichting', NJB 2010/1327, afl. 26 , p. $1652-1657$

12. Zie daarover J.S. Nan, N.L. Holvast, S.M.A. Lestrade, P.A.M. Mevis \& P. Mascini, Victa vincit veritas? Evaluatie Wet hervorming herziening ten voordele, Den Haag: WODC 2018, par. 4.3.1.

13. Kamerstukken II 2008/09, 32045, 3, p. 9-10, alsmede Kamerstukken II $2008 / 09,32045,5$, p. 3

14. HR 12 maart 2013, ECLI:NL:HR:2013:BZ2653, NJ 2013/437 m.nt. N. Keijzer (Tongzoen II), alsmede Kamerstukken I/ 2008/09, 32045, 3, p. 28; HR 25 juni 2013, ECLI:NL:HR:2013:73, NJ 2013/548 m.nt. T.M. Schalken; HR 25 juni 2013, ECLI:NL:HR:2013:74; HR 17 april 2018, ECLI:NL:HR:2018:605 en HR 18 maart 2008, ECLI:NL:HR: 2008:BA1024; HR 9 april 2019, ECLI:NL:HR:2019:546, NJ 2019/439 m.nt. P.A.M. Mevis.

15. HR 17 april 2018, ECLI:NL:HR:2018:605 en HR 18 maart 2008, ECLI:NL:HR:2008:BA1024. 
te zien, maar de overige elementen van het novumbegrip. ${ }^{16}$ Die zijn met reden door de wetgever behouden. In de vernieuwde wettelijke regeling werd nog steeds verlangd dat het gegeven nieuw moest zijn, dus de rechter nog niet bekend mocht zijn ten tijde van de berechting. Eveneens bleef in de wet opgenomen de eis dat door dat nieuwe gegeven het ernstige vermoeden ontstaat dat de oorspronkelijke rechter op een vrijspraak etc. zou zijn uitgekomen. Uit de wetsgeschiedenis van de Wet hervorming herziening ten voordele blijkt dat bewust aan die eisen is vastgehouden door de wetgever. Hij wilde het uitzonderlijke karakter van dit buitengewone rechtsmiddel behouden en het novumbegrip beperken/omlijnen, ondanks de verandering van enige (feitelijke) omstandigheid naar een gegeven. Alle elementen van het novumbegrip kunnen dus niet los van elkaar worden gezien en de bestaande term inzake het ernstige vermoeden is daarom overgenomen uit de oude bepaling. ${ }^{17}$

De eis dat het nieuwe gegeven naar verwachting een wezenlijk andere - zij het een bepaalde - uitspraak zal kunnen bewerkstelligen vindt zijn oorsprong in de regeling van $1899 .{ }^{18}$ In deze oudste voorloper van de huidige regeling werd hij al snel gesteld. In het wetgevingsproces van eind negentiende eeuw werd ook toen opgemerkt dat herziening een exceptioneel rechtsmiddel moest blijven en het novum 'tot ernstigen twijfel omtrent de juistheid der veroordeeling aanleiding moet geven'. De juistheid van de feitelijke beslissing moest twijfelachtig worden. Een vergelijking werd gemaakt met het Duitse en Belgische recht in dezen. ${ }^{19} \mathrm{Bij}$ de invoering van het huidige Wetboek van Strafvordering van 1926 was de gedachte over herziening als buitengewoon rechtsmiddel niet anders. De mogelijkheid tot een

16. Hij merkte dit op bij de vraag wanneer een deskundigenoordeel grond voor herziening kan vormen, zie Concl. A-G Bleichrodt 22 december 2015, ECLI:NL:PHR:2015:2769 (i.h.b. punt 50), bij HR 26 april 2016, ECLI:NL:HR:2016:736, NJ 2016/305 m.nt. J.M. Reijntjes.

17. Kamerstukken I/ 2008/09, 32045, 3, p. 9, 11 en 27; Kamerstukken II 2008/09, 32045, 6, p. 4 en Kamerstukken // 2011/12, 32044, 18, p. 47-48. De Hoge Raad heeft hiernaar al gewezen, zie onder meer HR 26 mei 2015, ECLI:NL:HR:2015:1326, NJ 2015/372 m.nt. B.F. Keulen en HR 18 december 2012, ECLI:NL:HR:2012:BW7190, NJ 2013/278 m.nt. T.M. Schalken (Zes van Breda). Zie ook de Conclusies van A-G Aben 9 april 2013, ECLI:NL:PHR:2013:391, bij HR 10 september 2013, ECLI:NL:HR:2013:673, NJ 2014/373 m.nt. B.F. Keulen; Concl. A-G Aben 11 juni 2013, ECLI:NL:PHR:2013:CA2549, bij HR 11 juni 2013, ECLI:NL:HR:2013:CA2549. De Hoge Raad houdt aan het vereiste strikt vast, zie recent HR 12 november 2019, ECLI:NL:HR:2019:1757.

18. Zie daarover J.W. Belinfante, Geschiedenis van de Wet van 14en juli 1899, Stbl. No. 159 tot wijziging van den 18en titel van het Wetboek van Strafvordering (Herziening van arresten en vonnissen): volledige verzameling van ontwerpen, gewisselde stukken, gevoerde beraadslagingen enz., 's-Gravenhage: Gebr. Belinfante 1899; W.H. Borgman, Van herziening van arresten en vonnissen (diss. Utrecht), Utrecht: Den Boer 1899; J.M. van Bemmelen, Strafvordering. Leerboek van het Nederlandse strafprocesrecht, 's-Gravenhage: Martinus Nijhoff 1950, p. 452-453; G.A.M. Strijards, Revisie. Inbreuken en executiegeschillen betreffende het strafgewijsde, Arnhem: Gouda Quint 1989, par. II.1; J. de Hullu, Over rechtsmiddelen in strafzaken (diss. Groningen), Arnhem: Gouda Quint 1989, hfdst. 10; Concl. A-G Aben 9 april 2013, ECLI:NL:PHR:2013:391, bij HR 10 september 2013, ECLI:NL:HR: 2013:673, NJ 2014/373 m.nt. B.F. Keulen, punt 3.1 en 3.3

19. BHTK $1898-99,78,8$, p. 19 andere uitspraak werd niet voldoende geacht. Verlangd werd een feit dat naar alle waarschijnlijkheid een andere uitspraak tot gevolg zou hebben gehad. Behouden bleef aldus de eis dat de nieuwe omstandigheid de aangevallen uitspraak in haar wezen zou aantasten. Ter vergelijking werd aan de Franse, Duitse en Oostenrijkse bepalingen gerefereerd. ${ }^{20}$

In de herzieningsregelingen van 1899, 1926 en 2012 is steeds, zij het soms na enig debat (waarover par. 3.1), bewust ervoor gekozen te verlangen dat de nieuwe omstandigheid of het nieuwe gegeven naar verwachting een andere uitspraak teweeg zou brengen (te weten een vrijspraak etc.). Bij de Modernisering verandert er ook op dit punt naar verwachting niets. ${ }^{21}$

\section{De discussie duurt voort}

\subsection{Het wettelijke novum}

Er blijven, zoals ik in de inleiding opmerkte, stemmen opgaan om de drempel voor een novum als grond voor herziening verder te verlagen. Bij de invoering van het 'moderne' herzieningsstelsel van 1899 was dat al het geval. De in de eerste ontwerpen gebruikte formuleringen luidden dat de nieuwe omstandigheid een andere uitspraak 'ten gevolge zou kunnen hebben' of daartoe 'zoude hebben kunnen leiden'. Maar dat werd aangepast naar 'ernstigen twijfel', omdat herziening geen verkapt beroep mocht worden. Al was het ook weer niet nodig dat de onschuld van de veroordeelde moest komen vast te staan en evenmin dat na herziening wel een vrijspraak etc. moest volgen bij de nieuwe behandeling. Over de formulering is bij de totstandkoming dus expliciet stilgestaan en is reeds de ook thans nog door sommigen gewenste insteek, (voor het eerst) verworpen. ${ }^{22}$

Bij de totstandkoming van de Wet herziening ten voordele in 2012 is eveneens geprobeerd een ruimer criterium in de wet te krijgen. Elk vermoeden, elke twijfel over de juistheid van de veroordeling, zou voldoende moeten zijn als een andere uitspraak zou volgen. ${ }^{23}$ Hierop werd vanuit de regering afwijzend gereageerd. Het zou het novum verder verruimen dan nodig was voor het oplossen van een in de praktijk gerezen probleem. Ook zou niet elk nieuw advies van een deskundige een

20. Kamerstukken // 1913/14, 286, 3, p. 157-158

21. Zie de conceptregeling van Boek 5 , Rechtsmiddelen, en de memorie van toelichting daarop (in concept), te vinden via https:// www.rijksoverheid.nl/documenten/publicaties/2017/11/13/ documenten-modernisering-wetboek-van-strafvordering.

22. Zie J.W. Belinfante, Geschiedenis van de Wet van 14en juli 1899, Stbl. No. 159 tot wijziging van den 18en titel van het Wetboek van Strafvordering (Herziening van arresten en vonnissen): volledige verzameling van ontwerpen, gewisselde stukken, gevoerde beraadslagingen enz., 's-Gravenhage: Gebr. Belinfante 1899, p. 44 e.v., alsmede W.H. Borgman, Van herziening van arresten en vonnissen (diss. Utrecht), Utrecht: Den Boer 1899, p. 81 e.v., met enige kritiek. Instemmend wel B.J. Stokvis, 'Revisie', TVS DI. XLI 1931, afl. 1, p. 43.

23. Kamerstukken || 2011/12, 32045, 8 en Kamerstukken /| 2011/12, 32044,18, p. 6. 
novum moeten opleveren. ${ }^{24}$ Het gegeven moest van voldoende gewicht zijn om aan te nemen dat een andere uitspraak zou zijn gedaan, omdat er altijd twijfel over de juistheid van een strafzaak kan bestaan (als voorbeeld werden zedenzaken genoemd). Alleen als door het nieuwe gegeven het ernstige vermoeden ontstaat dat de rechter anders zou hebben geoordeeld, was een heropening van een strafzaak volgens de minister opportuun. ${ }^{25}$

Maar hiermee was de kous niet af. Nadat de wet is ingevoerd is de discussie over een verlaging van de drempel namelijk niet verstomd. In 2017 werd daartoe bij de behandeling van de veiligheids- en justitiebegroting een motie ingediend door Kamerleden Van Nispen c.s. ${ }^{26}$ Het zou makkelijker moeten worden om justitiële dwalingen te herstellen, omdat zij schadelijk zijn voor het vertrouwen in de rechtsstaat. Uit nadere (parlementaire) stukken blijkt dat gekoerst wordt op een nieuw criterium dat zou moeten worden gehanteerd, luidende 'een reële mogelijkheid van een onterechte veroordeling'. Ook de term 'gerede twijfel' valt in dat verband, maar 'enige twijfel' zou niet voldoende zijn. ${ }^{27}$ Ook de ACAS pleit voorzichtig voor meer ruimte als zij signaleert dat maar weinig zaken door de Hoge Raad worden herzien. $^{28}$

De regering, althans de minister voor Rechtsbescherming, wil hiervan, mede met een beroep op het evaluatieonderzoek van 2018, evenwel nog steeds en bij herhaling niet weten. Aan het belang van rechtszekerheid zou door een verlaging van het criterium te veel afbreuk worden gedaan en het zal zorgen voor een hausse aan zaken. Herziening moet van de minister haar uitzonderlijke karakter behouden. Het huidige criterium is voor veel betrokkenen ook goed hanteerbaar. ${ }^{29}$

24. Kamerstukken I/ 2011/12, 32044, 18, p. 54, 56 en 58 en Kamerstukken // 2011/12, 32045, 24, p. 2.

25. Kamerstukken I 2011/12, 32045, C, p. 4-5.

26. Motie van Tweede Kamerlid Van Nispen c.s., Kamerstukken I/ 2016/17, $34550 \mathrm{VI}, 41$.

27. Algemeen Overleg van 12 september 2019, Kamerstukken II 2019/20, 29279,543 , p. 5, 7, 8, 20, 33-34 en M. van Nispen, 'Notitie voor de verruiming van de herziening ten voordele: Maak herstel justitiële dwalingen makkelijker', SP september 2019. Te raadplegen via: https:// www.sp.nl/sites/default/files/

190904_sp_notitie_justitiele_dwalingen_p_v02.pdf. Enige bijval hiervoor was tijdens het overleg te bespeuren, onder andere bij 50PLUS, bij monde van Kamerlid Krol.

28. V. Sebel (red.), Adviescommissie afgesloten strafzaken jaarverslag, 's-Gravenhage: ACAS 2017, p. 12: 'Wellicht dat dit wordt ingegeven door (te) strikte wettelijke omschrijvingen of interpretaties daarvan, waardoor het in de praktijk (te) moeilijk blijkt om tot een (begin van een potentieel) novum te kunnen komen. De vraag is dan ook of de huidige interpretatie van de herzieningswetgeving door de Hoge Raad voldoende ruimte biedt om potentieel onveilige veroordelingen te redresseren. Het is aan de wetgever om deze vraag te beantwoorden.'

29. Zie zijn standpunten in Kamerstukken // 2018/19, 29279, 495 en Kamerstukken I/ 2019/20, 29279, 543. In zijn oppositie c.q. bezwaren hiertegen stond de minister overigens niet alleen tijdens het Algemeen Overleg, ook het CDA vond, bij monde van Kamerlid Van Dam, een nadere verruiming niet nodig.

\subsection{Aanwijzingen voor een nader onderzoek}

Kritiek bestaat voorts over de met het wettelijke novumcriterium samenhangende kwestie van de aanleiding om een nader onderzoek naar het mogelijke bestaan van een novum in te stellen en de houding van de ACAS dienaangaande. De wet vertelt ons wat dat betreft het volgende. ${ }^{30}$ De procureur-generaal kan een verzoek van de gewezen verdachte tot het instellen van een nader onderzoek slechts afwijzen als er onvoldoende aanwijzingen zijn dat er mogelijkerwijs sprake is van een grond tot herziening (novum) of het verzochte onderzoek niet noodzakelijk is (art. 461 lid $3 \mathrm{~Sv}$ ). De ACAS adviseert over de wenselijkheid van een nader onderzoek (art. 462 lid $1 \mathrm{~Sv}$ ). Dat houdt in, ook volgens de wetgever, dat de aanwijzingen om toch weer op onderzoek uit te gaan dus wel in voldoende mate moeten bestaan voordat over de wenselijkheid daarvan positief geadviseerd kan worden door de ACAS en toewijzend kan worden beslist door de procureur-generaal. De benodigde aanwijzingen mogen van de wet en wetgever niet geheel ontbreken. Een fishing expedition is nadrukkelijk niet de bedoeling van een nader onderzoek door de procureur-generaal. ${ }^{31}$

In haar jaarverslag van 2013 stelde de ACAS over haar rol het volgende (p. 15): 'De Commissie acht nader onderzoek alleen zinvol indien redelijkerwijze te verwachten valt dat het mogelijk kan leiden tot een ernstig vermoeden als bedoeld in artikel 457, lid 1 onder c Sv.' Dat is haar wel op commentaar komen te staan. ${ }^{32}$ Sommigen vinden dat de ACAS hiermee te veel op de stoel van de Hoge Raad zit en te hoge eisen stelt aan de gronden die een gewezen verdachte in zijn verzoek moet aanvoeren om een positief advies van de ACAS aan de procureur-generaal te verkrijgen. Op te veel verzoeken wordt negatief geadviseerd (en overeenkomstig door de procureur-generaal beslist). ${ }^{33}$ Volgens Knoops valt uit de wetsgeschiedenis te destilleren dat 'van de ACAS juist een bijzondere en niet-restrictieve taak wordt verwacht'. De ACAS vat volgens hem haar wettelijke man-

30. Zie uitgebreider over het nader onderzoek J.S. Nan, N.L. Holvast, S.M.A. Lestrade, P.A.M. Mevis \& P. Mascini, Victa vincit veritas? Evaluatie Wet hervorming herziening ten voordele, Den Haag: WODC 2018, par. 2.2.5, 2.2.6 en 3.2.5.

31. Kamerstukken /I 2008/09, 32045, 6, p. 4; Kamerstukken I/ 2011/12, 32044, 18, p. 48 en 53 en Kamerstukken // 2008/09, 32045, 6, p. 2-3 en 13.

32. Kritisch is $\mathrm{Y}$. Buruma, 'Adviseren over afgesloten strafzaken', NJB 2016/1228, afl. 25, p. 1741, alsmede P.J. van Koppen \& R. Horselenberg, 'Waarom er in België en Nederland geen rechterlijke dwalingen zijn', E\&R 2018, afl. 6, p. 278-279.

33. Zie voor cijfers hierover en over de herzieningsaanvragen onderzoek J.S. Nan, N.L. Holvast, S.M.A. Lestrade, P.A.M. Mevis \& P. Mascini, Victa vincit veritas? Evaluatie Wet hervorming herziening ten voordele, Den Haag: WODC 2018, par. 3.2 en 4.2. 
daat te strikt op, nu zij vaak een negatief advies geeft. ${ }^{34}$ Tijdens het recente Algemeen Overleg was er wederom kritiek op het uitblijven van veel nadere onderzoeken. Zo meende Helder (PVV) dat de ACAS het bij het verkeerde eind had door als uitgangspunt aan te houden dat een nader onderzoek alleen maar zin had als redelijkerwijs valt te verwachten dat het tot een ernstig vermoeden kan leiden. Volgens haar zou dit niet uit de wetsgeschiedenis volgen, omdat in de wet staat dat het toereikend is dat er voldoende aanwijzingen bestaan dat er mogelijkerwijs sprake is van een grond voor herziening en dat dit ook zo in de memorie van toelichting is uitgelegd. De drempel is dus niet verlaagd, aldus Helder. ${ }^{35}$ Voorgesteld wordt nu dat voor de ACAS de 'onveilige veroordeling' de grondslag zou moeten zijn om een zaak serieus te onderzoeken. ${ }^{36}$

Knoops en Helder hebben gelijk dat het volgens de wet en wetgever voldoende is om een nader onderzoek in te stellen als er aanwijzingen bestaan voor een mogelijk novum. Zij zien echter over het hoofd dat de wettelijke eis is dat er voldoende aanwijzingen moeten zijn dat mogelijkerwijs sprake is van een novum als grond voor herziening. Daardoor wordt het mogelijke bestaan van een nieuw gegeven verlangd dat het ernstige vermoeden kan wekken dat de aangevallen veroordeling onjuist is. De mogelijkheid van het instellen van een nader onderzoek is aldus niet in het leven geroepen om de aanwijzingen voor (een) nader onderzoek te vinden. Pas bij het bestaan van voldoende aanwijzingen dat een novum tot de mogelijkheden behoort, is een diepgravend onderzoek op zijn plaats. Wet en wetsgeschiedenis zijn daarover duidelijk.

De vraag is ook of de ACAS (nog steeds) zo strikt haar taak opvat, zoals de kritiek luidt. Inmiddels hebben diverse (oud-)leden van de ACAS in het evaluatieonderzoek van 2018 aangegeven dat zij hun taak breed opvatten en het verzoek open en breed bezien. ${ }^{37}$ Zo staat het ook in recente jaarverslagen. De ACAS zoekt naar een potentieel onveilige veroordeling. ${ }^{38}$ Haar laatste advie-

34. G.G.J.A. Knoops, 'Herziening in strafzaken anno 2018: ten voordele of ten nadele?', NJB 2018/1646, afl. 31, p. 2322-2328. Zie eerder G.G.J.A. Knoops \& E.L.I. Bell, 'Herziening ten voordele in strafzaken: werkelijk een voordeel?', Strafblad 2014/3, p. 243-248. En Van Koppen en Horselenberg menen dat het wettelijke regime voor de ACAS te knellend is en in het vervolg ook voor de Hoge Raad. Zij bepleiten ook dat de ACAS meer onderzoek zou moeten doen en daarvoor een onderzoeksteam tot haar beschikking zou moeten krijgen. Zie P.J. van Koppen \& R. Horselenberg, 'Waarom er in België en Nederland geen rechterlijke dwalingen zijn', E\&R 2018, afl. 6, , p. 280-281.

35. Kamerstukken II 2019/20, 29279, 543, p. 9 (en p. 13, 25-26 en 35).

36. Zie de notitie van Van Nispen.

37. Zie over de bevindingen aangaande de taakopvatting van de ACAS J.S. Nan, N.L. Holvast, S.M.A. Lestrade, P.A.M. Mevis \& P. Mascini, Victa vincit veritas? Evaluatie Wet hervorming herziening ten voordele, Den Haag: WODC 2018, par. 3.3.7.

38. Al werken de eisen die aan een (potentieel) novum worden gesteld door de wet en de invulling daarvan door de Hoge Raad, wel door. V. Sebel (red.), Adviescommissie afgesloten strafzaken jaarverslag, 's-Gravenhage: ACAS 2017. V. Sebel (red.), Adviescommissie afgesloten strafzaken jaarverslag, 's-Gravenhage: ACAS 2018. Zie ook A.A. Franken, D.M. Markusse \& T.P.A.M. Wouters, 'Potentieel onveilige veroordelingen en de ACAS', E\&R 2018, afl. 6, p. 241-248. zen inzake de Arnhemse Villamoord-zaak maken dat ook duidelijk. Daarin wordt diverse malen gesteld dat die zaken voor haar als potentieel onveilig moeten worden gekwalificeerd en dat een nader onderzoek geboden is. ${ }^{39}$ Ook inzake de Rosmalense flatmoord heeft de ACAS tot een nader onderzoek geadviseerd en die zaak is thans aanhangig bij de Hoge Raad. ${ }^{40} \mathrm{Op}$ basis hiervan zou kunnen worden gezegd dat de ACAS de herzieningszaken aanvliegt zoals de wetgever dat bedoeld heeft én zoals anderen dat graag zien.

Wel is het van belang om te vermelden dat de ACAS niet zelf het diepgravende, nadere onderzoek verricht. Daartoe is zij niet opgericht en ook niet ingericht. Zij heeft slechts bescheiden onderzoeksbevoegdheden voor haar adviserende rol en die oefent zij soms uit. ${ }^{41}$ Bij de CEAS lag dat anders. Die commissie ging zelf heel actief op onderzoek uit en dat was ook haar raison d'être. ${ }^{42}$ En daarbij hoefde de CEAS zich, anders dan de ACAS, niet te bekommeren om het novumbegrip. Het was haar taak te zoeken naar ernstige manco's die zich in een specifieke strafzaak in de opsporing, vervolging en/ of de presentatie van het bewijs hebben voorgedaan. ${ }^{43}$ Er is wel voorgesteld dat de ACAS meer onderzoek zou moeten doen en daarvoor een onderzoeksteam tot haar beschikking zou moeten krijgen. ${ }^{44}$

\section{Mening van de herzieningspraktijk voor verlaging van het novumbegrip}

Voor een verlaging van de wettelijke drempel om herziening toe te laten op basis van een nieuw gegeven dat

39. Zaaknummers 022,026 en 028 , te vinden via https:// www.rechtspraak.nl/Organisatie-en-contact/Organisatie/Hoge-Raadder-Nederlanden/Over-de-Hoge-Raad/Bijzondere-taken-HR-en-PG/ Paginas/Overzicht-van-verzoeken-tot-nader-onderzoek.aspx. Of het echt om nova gaat in die zaak, wordt wel betwijfeld door P.J. van Koppen \& R. Horselenberg, 'Waarom er in België en Nederland geen rechterlijke dwalingen zijn', E\&R 2018, afl. 6, p. 280.

40. Zie de tussenuitspraak HR 13 november 2018, ECLI:NL:HR:2018:2095.

41. Volgens Van Koppen \& Horselenberg nog onvoldoende en zij stellen voor om een onderzoeksteam aan de ACAS toe te voegen. Zie P.J. van Koppen \& R. Horselenberg, 'Waarom er in België en Nederland geen rechterlijke dwalingen zijn', E\&R 2018, afl. 6, p. 276-281.

42. Zie over de CEAS J. de Ridder, C.M. Klein Haarhuis \& W.M. de Jongste, De CEAS aan het werk, Den Haag: Boom Juridische uitgevers 2008 en Y. Buruma, 'De nalatenschap van de CEAS (2006-2012)', in: M.S. Groenhuijsen, T. Kooijmans \& J.W. Ouwerkerk (red.), Roosachtig strafrecht (De Roos-bundel), Deventer: Kluwer 2013, p. 65-83.

43. Zie art. 2 Instellingsbesluit CEAS. Volgens haar eerste voorzitter, Buruma, ging die taak evenwel niet zo ver dat zonder aanwijzingen dat iemand ten onrechte was veroordeeld, zaken zouden worden geëvalueerd. Zie Y. Buruma, 'De nalatenschap van de CEAS (2006-2012)', in: M.S. Groenhuijsen, T. Kooijmans \& J.W. Ouwerkerk (red.), Roosachtig strafrecht (De Roos-bundel), Deventer: Kluwer 2013, p. 68 en later Y. Buruma, 'Adviseren over afgesloten strafzaken', NJB 2016/1228, afl. 25, p. 1741.

44. Zie P.J. van Koppen \& R. Horselenberg, 'Waarom er in België en Nederland geen rechterlijke dwalingen zijn', E\&R 2018, afl. 6, p. 280-281. 
'slechts' inhoudt dat de reële mogelijkheid bestaat dat de veroordeling onterecht is of daarover gerede twijfel bestaat, lijkt onvoldoende steun te vinden in de herzieningspraktijk. Wat dat betreft is voor een verlaging eigenlijk alleen steun te vinden bij advocaten en enkele wetenschappers die zich met herzieningszaken bezighouden. Daarbuiten menen praktiserende juristen en deskundigen dat met een verlaging van de drempel op dit punt, het instituut herziening tot een vierde instantie verwordt in plaats van een uitzondering te blijven. De aanzuigende werking, vooral op de verkeerde zaken (terechte veroordelingen dus), is ongewenst en over sommige zaken kan men nu eenmaal anders blijven denken. Voor slachtoffers en nabestaanden kan het vreselijk zijn dat toch weer discussie over een zaak ontstaat. Ook in dat verband is er alle reden vast te houden aan het ernstige vermoeden als scharnierpunt voor herziening bij een eerder onbekend gegeven. Een lagere maatstaf past volgens velen niet bij het karakter van herziening als buitengewoon rechtsmiddel. ${ }^{45}$

\section{Een korte vergelijking met het buitenland}

Herhaaldelijk heeft de wetgever, zo blijkt uit de vorige paragrafen, een beroep gedaan op vergelijkbare bepalingen in het buitenland om zijn novum in te richten. Het

lijkt daarom goed opnieuw diverse buitenlandse regelingen op dit punt te bezien. De gemene deler van deze onderzochte regelingen is dat de modaliteit van herziening ook in het buitenland uitzonderlijke gevallen regelt, waardoor de onherroepelijke uitspraak toch niet te handhaven is. De regelingen kennen vaak meer gronden dan wij. Op het punt van het novum en in het bijzonder de invulling van de eis van het ernstige ver-

45. Zie nader J.S. Nan, N.L. Holvast, S.M.A. Lestrade, P.A.M. Mevis \& P. Mascini, Victa vincit veritas? Evaluatie Wet hervorming herziening ten voordele, Den Haag: WODC 2018, par. 4.3.5 en J.S. Nan, N.L. Holvast, S.M.A. Lestrade, P.A.M. Mevis \& P. Mascini, 'Evaluatie van de Wet hervorming herziening ten voordele', NJB 2019/157, afl. 3, p. 190-191. Vlak voordat de recente wijziging op stapel stond, hamerde Corstens erop dat ervoor moest worden gewaakt dat herziening na eerste aanleg, hoger beroep en cassatie een vierde gewone instantie werd, met het gevaar dat met grote regelmaat strafprocessen zouden worden heropend. Dat kwam de rechtszekerheid niet ten goede. Zie G.J.M. Corstens, Het Nederlands strafprocesrecht, Deventer: Kluwer 2011, par. 17.7. Zijn opvolgers Borgers en Kooijmans zijn wat dat betreft geen andere mening toegedaan. Ook bij hen is geen kwaad woord over de eis van het ernstige vermoeden te vinden, zie G.J.M. Corstens, M.J. Borgers \& T. Kooijmans, Het Nederlands strafprocesrecht, Deventer: Wolters Kluwer 2018, par. 17.7. moeden leert een gang langs de buitenlandse velden het volgende. ${ }^{46}$

Ik begin bij Frankrijk. Daar bepaalt artikel 622 Code Procédure Pénal (CPP) dat herziening ('La révision') een exceptioneel rechtsmiddel is dat kan worden gevraagd ten voordele van de veroordeelde aan de hand van een nieuw feit of element dat zijn onschuld vaststelt of twijfel doet ontstaan aan zijn schuld. ${ }^{47}$ Tot 1989 moest de veroordeelde in Frankrijk met de nieuwe omstandigheid zijn onschuld aantonen. Sindsdien is het ook voldoende dat twijfel rijst over de schuld van de veroordeelde. ${ }^{48}$ Aangenomen wordt dat de geringste twijfel over de schuld van de veroordeelde, overeenkomstig de wil van de wetgever, tot revisie kan leiden. ${ }^{49}$ Deze regeling biedt op papier de ruimste mogelijkheid tot herziening wegens een novum. Maar de vereiste twijfel is door het Cour de révision (et de réexamen des condamnations pénales) van meet af aan behoorlijk strikt uitgelegd in de zin van serieuze twijfel. Daarom was het idee bij een vereenvoudiging van de herzieningsgronden dat de minste twijfel ('moindre doute') over de schuld van de aanvrager in de bepaling zou worden opgenomen. Daarvan is uiteindelijk afgezien omdat dit niet nodig zou zijn. Twijfel was nu eenmaal twijfel. Of die verandering verschil had gemaakt is maar de vraag. Het Cour de révision is huiverig om een rechterlijke uitspraak twijfelachtig te vinden. ${ }^{50}$ In de praktijk heeft het ruimere wettelijke novumcriterium wel tot meer herzieningsverzoeken geleid, maar nog steeds met zeer weinig succes. Het aantal zaken dat wordt herzien

46. De verdere inhoudelijke en formele aspecten en bijzonderheden van de buitenlandse herzieningsregelingen laat ik vrijwel onbesproken. Zie onder meer C.J.C.F. Fijnaut, 'De herziening in rechtsvergelijkend perspectief', NJB 2016/1230, afl. 25, p. 1749-1755. Zie tevens het addendum: C.J.C.F. Fijnaut, 'De herziening in rechtsvergelijkend perspectief. Een addendum over de situatie in Frankrijk en België', 15 augustus 2016, te raadplegen via: https://www.njb.nl/blog/Fijnaut-addendum; S. Bayer, Die Strafrechtliche Wiederaufnahme im deutschen, französischen und englischen Recht, Baden: Nomos 2019. Voor een mondiaal overzicht, zie B.L. Garrett, 'Towards an International Right to Claim Innocence', California Law Review 2017, p. 1173-1221.

47. Art. 622 luidt: 'La révision d'une décision pénale définitive peut être demandée au bénéfice de toute personne reconnue coupable d'un crime ou d'un délit lorsque, après une condamnation, vient à se produire un fait nouveau ou à se révéler un élément inconnu de la juridiction au jour du procès de nature à établir l'innocence du condamné ou à faire naître un doute sur sa culpabilité.'

48. Zie voor de achtergrond F. Fournié, 'Réviser la Révision. À propos de la nouvelle procédure de révision et de réexamen des condamnations pénales', La semaine juridique - édition générale 2014, afl. 27, p. $1326-1330$.

49. VIg. S. Bayer, Die Strafrechtliche Wiederaufnahme im deutschen, französischen und englischen Recht, Baden: Nomos 2019, p. 203 e.v. en F. Fournié, 'Réviser la Révision. À propos de la nouvelle procédure de révision et de réexamen des condamnations pénales', La semaine juridique - édition générale 2014, afl. 27, p. 1327.

50. VIg. D. Goetz, La révision en matière pénale (diss. Straatsburg), HAL archives ouvertes 2015, p. 234-235. Met dank aan prof. mr. Pieter Verrest. 
was en is laag. ${ }^{51}$ Er worden hoge eisen aan het novum gesteld.

Het tweede land is Engeland, ${ }^{52}$ omdat in veel discussies wordt aangegeven dat we in Nederland aansluiting zouden moeten zoeken bij de regeling van dat land. De minister voor Rechtsbescherming zal hierop begin 2020 uitgebreid terugkomen. Ik meld alvast dat in Engeland de Criminal Cases Review Commission (CCRC), dat is dus geen rechterlijk college, een zaak opnieuw naar de rechter kan sturen, onder meer als er een reële kans ('real possibility') is dat door nieuw bewijs of argument de uitspraak niet overeind zou blijven. Daarbij komt het aan op de vraag of de rechter waarnaar verwezen wordt de veroordeling als 'unsafe' zou bestempelen. ${ }^{53}$ De test is voor de CCRC, zo merkt zij op in de vaak aangehaalde zaak Pearson, wat vaag maar 'plainly denotes a contingency which, in the Commission's judgement, is more than an outside chance or a bare possibility but which may be less than a probability or a likelihood or a racing certainty'. 54

De CCRC wordt vanuit de praktijk wel bekritiseerd omdat te weinig zaken zouden worden verwezen, maar niet iedereen is het met die kritiek eens. In het Verenigd Koninkrijk houdt men aan het criterium vast, al mag de real possibility-test wel wat minder strikt worden gehan-

51. Zie voor recente cijfers B.L. Garrett, 'Towards an International Right to Claim Innocence', California Law Review 2017, p. 1204. J. Pradel, Procédure pénale, Paris: Éditions Cujas 2017, p. 998-999, heeft oudere cijfers over herziening in de jaren 1985-2003 (respectievelijk 1, 0, 1, 3, 5, $0,4,0,1,51,5,7,3,0,6,3,3$ en 1).

52. En Wales. Voor Noord-lerland gelden soortgelijke regels, zie art. 10 en 12 Criminal Appeal Act 1995 (CAA 1995). Over herziening in Engeland uitgebreid C. Hoyle \& M. Sato, Reasons to Doubt: Wrongful Convictions and the Criminal Cases Review Commission, Oxford: Oxford University Press 2019, alsmede M. Naughton, 'The Criminal Cases Review Commission: Innocence Versus Safety and the Integrity of the Criminal Justice System', 58 Crim. L.Q. 2012, p. 207-244; J. Weeden, 'The Criminal Cases Review Commission (CCRC) of England, Wales and Northern Ireland', 58 Crim. L.Q. 2012, p. 191-206. Zie handzaam en in het Nederlands C.J.C.F. Fijnaut, 'De herziening in rechtsvergelijkend perspectief', NJB 2016/1230, afl. 25, p. 1749-1755 en C.H. Brants \& A.A. Franken, 'Over de Criminal Cases Review Commission en de Commissie evaluatie afgesloten strafzaken', DD 2006/51, afl. 7, p. 734-754.

53. Art. 13 CAA 1995 in verbinding met art. 2 CCA 1968. Art. 13 CAA 1995 houdt in: 'A reference of a conviction, verdict, finding or sentence shall not be made (...) unless - (a) the Commission considers that there is a real possibility that the conviction, verdict, finding or sentence would not be upheld were the reference to be made, the Commission so consider - (i) in the case of a conviction, verdict or finding, because of an argument, or evidence, not raised in the proceedings which led to it or on any appeal or application for leave to appeal against it.'

54. $R v$ Criminal Cases Review Commission ex parte Pearson [1999] 3 All ER 498. Ook aangehaald in C. Hoyle \& M. Sato, Reasons to Doubt: Wrongful Convictions and the Criminal Cases Review Commission, Oxford: Oxford University Press 2019, p. 30. De overweging houdt verder in: 'The Commission is entrusted with the power and the duty to judge which cases cross the threshold and which do not ... In a conviction case depending on the reception of fresh evidence, the Commission must ask itself a double question: do we consider that if the reference is made there is a real possibility that the Court of Appeal will receive the fresh evidence? If so, do we consider that there is a real possibility that the Court of Appeal will not uphold the conviction? The Commission would not in such a case refer unless it gave an affirmative answer to both questions.' teerd van de Fustice Committee. ${ }^{55}$ Recente, algemene cijfers van de CCRC zelf laten zien dat weinig zaken opnieuw aan de rechter worden voorgelegd - laat staan dat de zaak over zou moeten. ${ }^{56}$ Zij kreeg sinds april 1997 tot heden 25.497 zaken binnen (inclusief die welke nietontvankelijk waren) en deed er tot op heden 24.713 af. Er werden 667 zaken doorgestuurd naar de Engelse rechter, waarvan 441 beroepen werden toegelaten en 203 werden afgewezen. Het gaat hierbij dus niet alleen om zaken die op basis van het novum zijn beoordeeld. In Engeland zijn ze uiteindelijk dus niet zo scheutig met het heropenen van strafzaken. ${ }^{57}$

In België heeft de regeling enkele wijzigingen ondergaan en is herziening op grond van een novum thans op een grotendeels identieke wijze als bij ons, geregeld in artikel 443 sub 3 van het Belgische Wetboek van Strafvordering. Tot 1 maart 2019 was vereist dat door het nieuwe bewijs de onschuld van de veroordeelde kon volgen. ${ }^{58}$ Maar nu kan herziening worden aangevraagd als door een nieuw gegeven het ernstige vermoeden bestaat dat een vrijspraak etc. zou zijn gevolgd. ${ }^{59}$ Daarmee was bij onze zuiderburen tot voor kort sprake van een veel hogere eis inzake het novum dan bij ons, waar voldoende uitzicht op een vrijspraak steeds voldoende is geweest. In Duitsland is herziening ('Die Wiederaufnahme') bij een novum toegelaten op grond van artikel 359 sub 5 Strafprozeßordnung (StPO). ${ }^{60}$ De nieuwe feiten of bewijsmiddelen ('Tatsachen oder Beweismittel') moeten 'geeignet' zijn ervoor te zorgen dat de veroordeelde zou zijn vrijgesproken etc. De eis van 'Geeignetheit' is van grote praktische betekenis en het centrale punt van deze herzieningsgrond. De eis wordt zo ingevuld dat deze nieuwe gegevens 'ernstliche Zweifel und der Richtigkeit der Verurteilung in tatsächlicher

55. Zie het verslag van de Justice Committee 2015 (te vinden via https:// publications.parliament.uk/pa/cm201415/cmselect/cmjust/ 850/85005.htm\#n9). Zie tevens C.J.C.F. Fijnaut, 'De herziening in rechtsvergelijkend perspectief', NJB 2016/1230, afl. 25, p. 1752.

56. Zie 'CCRC Statistics', https://ccrc.gov.uk/case-statistics/ (voor het laatst geraadpleegd op 26 november 2019)

57. Zie ook C.H. Brants \& A.A. Franken, 'Over de Criminal Cases Review Commission en de Commissie evaluatie afgesloten strafzaken, DD 2006/51, afl. 7, p. 734-754, met oudere cijfers.

58. C. Van den Wyngaert, P. Traest \& S. Vandromme, Strafrecht en strafprocesrecht, Antwerpen-Apeldoorn: Maklu 2017, p. 1392-1393 en R. Declercq, Beginselen van Strafrechtspleging, Mechelen: Kluwer 2014, p. 1841.

59. Art. 443 sub 3 Sv houdt in dat herziening kan worden aangevraagd: 'Wanneer er sprake is van een gegeven dat bij het onderzoek op de terechtzitting aan de rechter niet bekend was en waarvan de veroordeelde het bestaan niet heeft kunnen aantonen ten tijde van het geding en dat, op zichzelf of in verband met de vroeger geleverde bewijzen, met de uitspraak niet bestaanbaar schijnt, zodanig dat het ernstige vermoeden ontstaat dat indien dit gegeven bekend zou zijn geweest, het onderzoek van de zaak zou hebben geleid, hetzij tot een vrijspraak van de veroordeelde, hetzij tot het verval van de strafvordering, hetzij tot het ontslag van rechtsvervolging, hetzij tot de toepassing van een minder strenge strafwet.'

60. Art. 359 sub StPO bepaalt dat herziening mogelijk is: 'wenn neue Tatsachen oder Beweismittel beigebracht sind, die allein oder in Verbindung mit den früher erhobenen Beweisen die Freisprechung des Angeklagten oder in Anwendung eines milderen Strafgesetzes eine geringere Bestrafung oder eine wesentlich andere Entscheidung über eine Maßregel der Besserung und Sicherung zu begründen geeignet sind'. 
Hinsicht zu begründen geeignet sind'. De Duitsers leggen de lat in dezen dus bij ernstige twijfel. ${ }^{61}$

'La revisión' wordt in Spanje toegestaan bij nieuw bewijsmateriaal dat zou hebben gezorgd voor een vrijspraak of de toepasselijkheid van een minder zware strafbepaling. ${ }^{62}$ De invulling van dit criterium door de Spaanse Hoge Raad (Tribunal Supremo) hangt af van de omstandigheden van het geval, maar het nieuwe bewijs moet ondubbelzinnig tot de conclusie leiden dat de veroordeelde onschuldig is (inclusief onder meer de toepasselijkheid van strafuitsluitingsgronden). ${ }^{63}$ In Portugal is wettelijk bepaald dat een zaak onder meer kan worden herzien als er naar aanleiding van 'vers' bewijs ernstige twijfel bestaat over de juistheid van de veroordeling. ${ }^{64}$ In Polen, ten slotte, is in heropening van de zaak ('wniosek o wznowienie postępowania') bij nieuwe feiten voorzien in artikel 540 lid 1 sub 2 van het Poolse Wetboek van Strafvordering. Het nieuwe bewijs moet wezenlijk van betekenis zijn en de juistheid van de feitelijke beoordeling aantasten. Het moet ertoe leiden dat het hoogstwaarschijnlijk is dat na heropening de zaak een andere uitkomst zal hebben. ${ }^{65}$

De snelle vergelijking die met de ons omringende landen en de kring daaromheen valt te maken, is dat ook daar in beginsel een hoge of strenge maatstaf wordt gehanteerd om bij een nieuw gegeven een zaak te laten herzien. Alleen in Frankrijk is (elke) twijfel wettelijk voldoende. In alle andere besproken landen wordt met verschillende formuleringen en de invulling daarvan de eis gesteld dat het nieuwe gegeven het ernstige vermoeden wekt, ernstige twijfel zaait etc. dat de oorspronkelijke veroordelende uitspraak onjuist is en met de nieuwe ontwikkelingen de rechter tot een vrijspraak etc. zou zijn gekomen. Ook in Engeland is, zo blijkt, met de 'real possibility'-maatstaf het niet zo dat bij de vleet zaken opnieuw aan de rechter worden voorgelegd. De theorie en praktijk van herziening houdt eigenlijk in alle behan-

61. Zie S. Bayer, Die Strafrechtliche Wiederaufnahme im deutschen, französischen und englischen Recht, Baden: Nomos 2019, p. 139 e.v., alsmede M. Heghmanns \& U. Scheffler, Handbuch zum Strafverfahren, München: Beck 2008, p. 1104 e.v., U. Eisenberg, Beweisrecht der StPO, München: Beck 2012, p. 190-193 en K. Marxen \& F. Tiemann, Die Wiederaufnahme in Strafsachen, Heidelberg: Müller 2006, p. 61 e.v. (die spreken van 'ernsthafte Zweifel')

62. Art. 954 lid 1, aanhef en sub d Ley de Enjuiciamiento Criminal luidt: '1. Se podrá solicitar la revisión de las sentencias firmes en los casos siguientes: (...) d) Cuando después de la sentencia sobrevenga el conocimiento de hechos o elementos de prueba, que, de haber sido aportados, hubieran determinado la absolución o una condena menos grave.'

63. Met dank aan informatie verstrekt door dr. Antonio Martínez Santos van de universiteit Francisco de Vitoria.

64. Art. 449 lid 1 sub d van het Portugese Wetboek van Strafvordering luidt in het Engels: '1. A judgment which has become final may be reviewed on the following grounds: (...) (d) after delivery of the final judgment, fresh evidence has been discovered casting serious doubt on the validity of the conviction.' Informatie ontleend aan EHRM 5 juli 2011, ECLI:CE:ECHR:2011:0705JUD001980808, par. 27 (Moreira Ferreira/ Portugal), NJ 2019/280 m.nt. P.A.M. Mevis.

65. Met dank aan informatie verstrekt door dr. Karolina Kremens van de Universiteit van Wroclaw. Zie Supreme Court Decision 29.05.2010, V KP 68/11, LEX no. 1212379. Zie voor de heropening van strafzaken ook W. Jasinski \& K. Kremens, Criminal law in Poland, Wolters Kluwer International 2019, p. 276 delde landen in dat - net als in Nederland - strak wordt vastgehouden aan het uitgangspunt dat aan de uitkomst van een onherroepelijke veroordeling niet snel wordt getornd.

\section{Slotsom; if it ain't broke, don't fix it}

Het belang van rechtszekerheid laat een aantasting van het gezag van gewijsde niet snel toe. Dat neemt niet weg dat die veroordeling uiteraard wel via een eerlijk en zorgvuldig proces tot stand moet zijn gekomen. En niemand zal betogen dat fouten in de strafrechtspleging niet voorkomen en dat het belang van rechtszekerheid altijd voorgaat. Die tijden zijn allang voorbij. Ook na een onherroepelijke veroordeling dient er een voorziening te zijn om onjuiste beslissingen te redresseren. Herziening ten voordele is een onmisbare remedie in ons (gesloten) systeem van rechtsmiddelen. Het is goed dat de politiek zich justitiële vergissingen blijft aantrekken en zich bijvoorbeeld druk maakt om de financiering van het herstel daarvan. Maar uit het voorgaande wordt duidelijk dat er geen goede reden aanwezig is om het wettelijke novumbegrip te verlagen, bijvoorbeeld tot de vraag of een reële mogelijkheid bestaat dat de veroordeling onterecht is of dienaangaande gerede twijfel aanwezig is. De nieuwe ontwikkeling in een afgesloten strafzaak moet een wezenlijk ander licht op de veroordeling schijnen en deze ogenschijnlijk onhoudbaar doen lijken. Die opstelling sluit aan bij het karakter van herziening. Aangenomen wordt dat, om met Blok en Besier te spreken, niet lichtvaardig een inbreuk kan worden gemaakt op de uitgangspunten dat aan een onherroepelijke uitspraak gezag van gewijsde toekomt (auctoritas rei iudicatae) en dat over de uitkomst daarvan niet steeds doorgeprocedeerd kan worden (lites finiri oportet). ${ }^{66} \mathrm{Als}$ wordt uitgegaan van een reële kans op een onterechte veroordeling, wordt dat uitgangspunt te veel verlaten. Andere landen houden, niet voor niets, ook vast aan een vergelijkbaar strenge toets inzake het novum als wij. De Franse wettelijke maatstaf is met 'doute' over de schuld van de veroordeelde zeer laag, maar in de praktijk heeft dat nog niet tot een significant aantal geslaagde herzieningsverzoeken geleid.

In het verlengde van de discussie over de verruiming van het novumcriterium moet ook niet worden gesleuteld aan de wettelijke maatstaf waarmee de ACAS kijkt of de procureur-generaal een nader onderzoek dient in te stellen. Anders zou herziening in de eerste fase haar

66. A.J. Blok \& L.Ch. Besier, Het Nederlandsche strafproces deel I, Haarlem: Tjeenk Willink 1925, p. 489. Zie ook uitgebreid G.A.M. Strijards, Revisie. Inbreuken en executiegeschillen betreffende het strafgewijsde, Arnhem: Gouda Quint 1989; G.A.M. Strijards, 'Revisie bij de Hoge Raad', in: De derde rechtsingang nader bekeken (Bronkhorst-bundel), Arnhem: Gouda Quint 1989, p. 265-297; R.E.P. de Ranitz, Herziening van arresten en vonnissen (diss. Leiden), Alphen aan den Rijn: Tjeenk Willink 1977. 
karakter als exceptie verliezen. Eerder dan bij wezenlijke aanknopingspunten voor de aanwezigheid van een rechterlijke dwaling moet de ACAS over de wenselijkheid van een nader onderzoek door de procureur-generaal niet positief adviseren. ${ }^{67}$ Dat de ACAS initieel breder kijkt, zeker als zij onraad ruikt, lijkt mij natuurlijk goed. ${ }^{68}$ Maar het is, ondanks de kritiek, geen goed idee om haar taak wettelijk te verbreden. ${ }^{69}$ Dan zouden haar werk en adviezen niet aansluiten op de taak van de procureur-generaal en diens te nemen beslissing op het verzoek, omdat die een nader onderzoek immers pas dient in te stellen als de kans op een novum als grond voor herziening bestaat. De wet is niet voor niets zo ingericht. $\mathrm{Nu}$ de Hoge Raad uiteindelijk beoordeelt - en ook moet beoordelen - of een aangedragen, de rechter eerder onbekend gebleven, gegeven het ernstige vermoeden wekt dat deze dan tot een vrijspraak etc. zou zijn gekomen, moet het voorwerk van de ACAS daarvan niet losgekoppeld worden. Het systeem - een advies van de ACAS over het verzoek tot een nader onderzoek, de beslissing van de procureur-generaal daarop en vervolgens de beslissing van de Hoge Raad op een eventuele herzieningsaanvraag - is thans één sluitend geheel. ${ }^{70}$ Het met een bredere blik adviseren over een in te stellen nader onderzoek zou betekenen dat het paard achter de wagen wordt gespannen, omdat hetgeen een nader onderzoek zou (kunnen) opdiepen, in veel gevallen toch niet tot herziening zou (kunnen) leiden. Dat is geen goede gang van zaken. Het is evenmin een efficiënte besteding van het justitiebudget. Bij gewezen verdachten zou die insteek veelal alleen maar tot meer teleurstelling leiden. ${ }^{71}$ En voor slachtoffers en/of nabestaanden geldt dat het onwenselijk zal zijn dat de zaak onnodig wordt opgerakeld.

67. Zie ook J.S. Nan, N.L. Holvast, S.M.A. Lestrade, P.A.M. Mevis \& P. Mascini, 'Evaluatie van de Wet hervorming herziening ten voordele', NJB 2019/157, afl. 3, p. 188-189 alsmede J.S. Nan, N.L. Holvast, S.M.A. Lestrade, P.A.M. Mevis \& P. Mascini, Victa vincit veritas? Evaluatie Wet hervorming herziening ten voordele, Den Haag: WODC 2018.

68. Of zij daartoe een onderzoeksteam tot haar beschikking zou moeten hebben vraag ik mij af. Dan bevinden we ons toch weer in een voorportaal van een vierde (opnieuw feitelijke) instantie na de eerste aanleg, hoger beroep en cassatie. Voor een nader onderzoek lijkt wettelijk pas plaats als de gewezen verdachte met in potentie baanbrekende gegevens komt en niet eerder. Een nader onderzoek is er niet om een kans op de mogelijkheid daarop te scheppen. De ACAS is daar evenmin voor. De gewezen verdachte zal met voldoende aanleiding bij de procureurgeneraal moeten aankloppen om de ACAS en de procureur-generaal in beweging te krijgen.

69. Overigens is het opvallend dat de kritiek zich richt op de opstelling van de ACAS en niet zozeer op de procureur-generaal, terwijl laatstgenoemde uiteindelijk toch over het verzoek tot het instellen van een nader onderzoek gaat. De reden kan zijn dat de procureur-generaal de adviezen tot nu toe in essentie steeds heeft gevolgd. De ACAS fungeert in deze een beetje als bliksemafleider voor de procureur-generaal.

70. Daarbij heeft nog te gelden dat het enkele feit dat de Hoge Raad tot herziening besluit, nog niet meebrengt dát de - dan weer - verdachte uiteindelijk wordt vrijgesproken etc. Dat is aan het hof waarnaar de zaak wordt verwezen. Een treffend voorbeeld is de afloop van de Zes van Breda. Daarin bleven de veroordelingen gehandhaafd, HR 19 december 2017, ECLI:NL:HR:2017:3189, NJ 2018/251 m.nt. J.M. Reijntjes.

71. Op zich is ook Buruma daarvoor beducht. Zie Y. Buruma, 'Adviseren over afgesloten strafzaken', NJB 2016/1228, afl. 25, p. 1741.
Aangaande de beide in dit stuk door de oppositie aangehangen wijzigingen geldt dat zij zich niet verhouden tot herziening ten voordele als buitengewoon rechtsmiddel. $\mathrm{Zij}$ vinden dan ook terecht geen gehoor bij de (moderne) wetgever. Het huidige evenwicht dat is gevonden tussen de (rechts)zekerheid dat aan een veroordeling wordt vastgehouden en de mogelijkheid dat een veroordeelde bij (potentieel) gemichtige nieuwe ontwikkelingen toch weer beschermd wordt door het recht en bij de procureur-generaal en de Hoge Raad kan aankloppen om zijn zaak opnieuw onderzocht respectievelijk herzien te krijgen, lijkt te werken en zou anders worden verstoord. Het houdt een keer op. 